\title{
Long-distance dispersal of a male puma (Puma concolor puma) in Patagonia
}

\author{
Dispersión de larga distancia de un puma (Puma concolor puma) macho en Patagonia
}

MARK ELBROCH ${ }^{1, *}$, HEIKO U. WITTMER ${ }^{1}$, CRISTIÁN SAUCEDO $^{2} \&$ PAULO CORTI $^{3}$

\footnotetext{
${ }^{1}$ Wildlife, Fish, and Conservation Biology, University of California, One Shields Ave., Davis, CA 95616, USA

${ }^{2}$ Conservación Patagónica, Patagonia Park, Cochrane, Chile

${ }^{3}$ Instituto de Zoología, Universidad Austral de Chile, Casilla 567, Valdivia, Chile

* Corresponding author: 1melbroch@ucdavis.edu
}

Pumas (Puma concolor Linnaeus, 1771) have the largest geographic range of any terrestrial mammal in the Americas. Despite this large distribution, pumas are a species of conservation concern and believed in decline across much of their range (Caso et al. 2008). Research in North America suggests that dispersal is critical in maintaining connectivity of increasingly fragmented puma populations (Beier 1995, Sweanor et al. 2000, Stoner et al. 2006, Robinson et al. 2008). Puma dispersal maintains genetic diversity across the landscape and is essential in revitalizing small populations and recolonizing habitats in which local populations have become extinct (i.e., source-sink dynamics) (Beier 1995, Stoner et al. 2006, Robinson et al. 2008, Stoner et al. 2008). Long distance dispersals by pumas across large tracts of unsuitable habitat have been well recorded in North America (e.g., Logan \& Sweanor 2001, Thompson \& Jenks 2005, Stoner et al. 2008). Here we report on a long-distance dispersal event of a male Patagonian puma (Puma concolor puma) in South America as revealed by satellite and GPS telemetry.

Our ongoing study of pumas is located in the Aysen District, Chile. The study area covers approximately 120,000 ha and includes the Lago Cochrane National Reserve $(6,925$ ha), the private Estancia Valle Chacabuco $(69,000 \mathrm{ha})$ and the southern portions of the Jeinimeni National Reserve $(161,100$ ha). The habitat is characteristic of rugged Patagonia mountains, and supports large numbers of native guanacos (Lama guanicoe Müller, 1776) and a small population of endangered huemul (Hippocamelus bisulcus Molina, 1782). European hares (Lepus europaeus Pallas, 1778) are abundant. Culpeo foxes (Lycalopex culpaeus Molina, 1782) and several scavenger birds, such as Andean condor (Vultur gryphus Linnaeus, 1758), caracara (Polyborus plancus Miller, 1777), and black-chested buzzard eagle (Geranoaetus melanoleucus Vieillot, 1819) are common. Extensive sheep farming is the most common land use in the areas surrounding the reserve.

In spring 2008, we began a pilot study of pumas to test equipment and field logistics. We captured five pumas using hounds and fitted them with GPS collars (M. Elbroch, unpublished data). The first puma captured on the $12^{\text {th }}$ of April was a subadult male of approximately 2.5 years (aged using tooth condition; Heffelfinger 1997). The puma was fitted with a SirTrack ARGOS GPS collar, programmed to acquire fixes three times per day. From the location data, we estimated dispersal distance using three different methods. First, we calculated the straight-line distance between the capture point and the last location we recorded (Thompson \& Jenks 2005). Second, we calculated the dispersal distance as a) the sum of straight-line vectors overlaid on travel routes (i.e., excluding side excursions and back tracking) and b) the cumulative distance calculated by summing all distances between each successful fix (Stoner et al. 2008).

We gathered data on Puma 1 for 112 days, before his collar stopped sending data. For 48 
days, Puma 1 remained in our study area and utilized an area $199 \mathrm{~km}^{2}$ in size (Minimum Convex Polygon, ArcGIS 9.1). Average daily movements \pm SD during this period were $6.3 \pm$ $6.58 \mathrm{~km} \mathrm{day}^{-1}$; range 0.36-23.61). On May $5^{\text {th }}$, the puma permanently departed the study area and moved east into Argentina and then south paralleling the border between Chile and Argentina. Average daily movements \pm SD during his dispersal period were $11.7 \pm 7.45 \mathrm{~km}$ day $^{-1}$ (range 0.83-33.98). The total recorded dispersal distances were $167 \mathrm{~km}$ (straight-line), $363 \mathrm{~km}$ (sum of straight-line vectors) and 757.4 $\mathrm{km}$ (cumulative distance between each successful fix) (Fig. 1). We underwent a site investigation at the last recorded position, and confirmed that the puma had been killed on a sheep farm near Tuco Tuco, Argentina.



Fig. 1: Movement data for Puma 1.

Datos de movimiento para el Puma 1. 
The long observed dispersal distance suggests the potential for metapopulation dynamics (Beier 1995, Sweanor et al. 2000, Stoner et al. 2006, Robinson et al. 2008) in southern South America, even in areas where pumas continue to be heavily persecuted (Franklin et al. 1999). In southern South America the clear boundaries between more rugged, protected areas with higher densities of wild prey, and more accessible areas with active sheep ranching suggest the potential for source-sink dynamics. Observed movements and mortality of this collared individual highlight the need for large-scale puma studies in South America. In addition, more information is required to better understand the extent to which inhospitable matrix are a barrier to puma movements and the long term persistence of pumas in protected areas. We suggest that large scale studies in southern South America include both genetic tools to assess gene flow, and telemetry to better understand the influence of matrix habitat between protected areas on the viability of increasingly fragmented puma populations.

Initial funding for this work was generously provided by the National Geographic Society, Conservación Patagonica, Felidae Conservation Fund, Pacific Rim Research Program, and the Hemispheric Institute on the Americas. We are thankful to all people who helped in the capturing of pumas, particularly SAG (Chile Agricultural and Cattle Service), Arcilio Sepúlveda and Boone Smith.

\section{LITERATURE CITED}

BEIER P (1995) Dispersal of juvenile cougars in fragmented habitat. Journal of Wildlife Management 59: 228-237.

CASO A, C LÓPEZ-GONZÁLEZ, E PAYAN, E EIZIRIK, T DE OLIVEIRA, R LEITE-PITMAN, M KELLY, C VALDERRAMA \& M LUCHERINI (2008) Puma concolor. In: IUCN Red List of Threatened Species. URL:http://www.iucnredlist.org/. (accessed on 30 January 2009).

FRANKLIN WL, WE JOHNSON, RJ SARNO, \& JA IRIARTE (1999) Ecology of the Patagonia puma in southern Chile. Biological Conservation 90: 33-40.

HEFFELFINGER J (1997) Age criteria for Arizona game species. Special Report \#19, Arizona Game and Fish Department: 25-26.

LOGAN KA \& LL SWEANOR (2001) Desert puma: Evolutionary ecology and conservation of an enduring carnivore. Island Press, Washington. $463 \mathrm{pp}$.

ROBINSON HS, RB WIELGUS, HS COOLEY \& SW COOLEY (2008) Sink populations in carnivore management: Cougar demography and immigration in a hunted population. Ecological Applications 18: 1028-1037

STONER DC, ML WOLFE \& DM CHOATE (2006) Cougar exploitation levels in Utah: implications for demographic structure, population recovery, and metapopulation dynamics. Journal of Wildlife Management 70: 1588-1600.

STONER DC, WR RIETH, ML WOLFE, MB MECHAM \& A NEVILLE (2008) Long-distance dispersal of a female cougar in a basin and range landscape. Journal of Wildlife Management 72: 933-939.

SWEANOR LL, KA LOGAN \& MG HORNOCKER (2000) Cougar dispersal patterns, metapopulation dynamics, and conservation. Conservation Biology 14: 798-808

THOMPSON DJ, \& JA JENKS (2005) Long-distance dispersal by a subadult male cougar from the Black Hills, South Dakota. Journal of Wildlife Management 69: 818-820. 
